\title{
Herbage intake in Danish Jersey and Danish Holstein steers on perennial ryegrass/white clover pasture
}

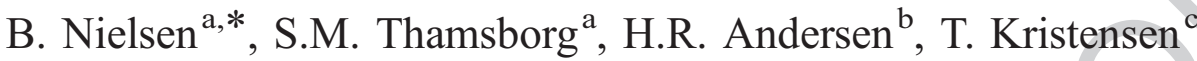 \\ ${ }^{a}$ Organic Animal Health and Production, Department of Animal Science and Animal Health, Royal Veterinary Agricultural University, \\ Groennegaardsvej 2, DK-1870 Frederiksberg C, Denmark \\ ${ }^{\mathrm{b}}$ Department of Animal Nutrition and Physiology, Danish Institute of Agricultural Sciences, Foulum, Postbox 50, 8830 Tjele, Denmark \\ ${ }^{\mathrm{c}}$ Department of Agricultural Systems, Danish Institute of Agricultural Sciences, Foulum, Postbox 50, 8830 Tjele, Denmark \\ Received 31 December 2002; received in revised form 16 June 2003; accepted 2 September 2003
}

\section{Abstract}

The objective of this study was to estimate herbage intake in Danish Holstein and Danish Jersey steers at an age of 8-9 months on ryegrass/white clover pasture. The steers were turned out on pasture in late April and herbage intake was estimated in June in steers of a mean liveweight ( \pm S.D.) of $264 \pm 14$ and $185 \pm 25 \mathrm{~kg}$ for Danish Holstein and Danish Jersey, respectively. Faeces and herbage samples were analysed for alkanes to estimate herbage dry matter intake, dry matter digestibility (DMD) and botanical composition of intake. The weight gains at the time of herbage intake estimation in June ( $\mathrm{kg} / \mathrm{day})$ were $1.142 \pm 265$ and $0.927 \pm 168 \mathrm{~kg} /$ day for Danish Holstein and Danish Jersey, respectively. Daily herbage intake (kg dry matter $(\mathrm{DM})$ ) estimated by alkanes $\mathrm{C}_{32} / \mathrm{C}_{33}$ was $8.33 \pm 0.97$ and $6.28 \pm 0.61$ per day $(P<0.001)$ and $3.15 \pm 0.32$ and $3.43 \pm 0.30$ per $100 \mathrm{~kg}$ liveweight $(\mathrm{LW})(P<0.05)$ for Danish Holstein and Danish Jersey, respectively. The botanical composition of the diet was the same for Danish Holstein and Danish Jersey with about half of the diet being grass leaves and the other half clover leaves. It is concluded that Danish Jersey steers have higher herbage intake per $100 \mathrm{~kg} \mathrm{LW}$ than Danish Holstein steers of the same age, but herbage intake per kg metabolic LW is not different between the two breeds.

(C) 2003 Published by Elsevier B.V.

Keywords: Alkane method; Breeds; Grazing; Intake; Organic farming; Steers

\section{Introduction}

Jersey cattle are supposed to have a higher feed intake capacity per $100 \mathrm{~kg} \mathrm{LW}$ compared to Holstein Friesians, especially when fed high levels of roughages (Ingvartsen and Weisberg, 1993). High levels of roughage and grazing in the summertime are used in

* Corresponding author. Tel.: +45-35283082; fax: +4535283055 .

E-mail address: bean@kvl.dk (B. Nielsen). organic beef production to fulfill the European standards for organic livestock production (CEC, 1999). Thus Jersey cattle could be an excellent resource for organic beef production based on high levels of roughages. Although, 59\% of all Jersey bull calves born on organic farms in Denmark are killed, due to expected poor economy in beef production based on dairy breeds, and because it is difficult to sell Jersey calves to conventional farmers for fattening (Nielsen and Thamsborg, 2002). Especially killing of newborn calves may be considered a serious ethical problem 
for organic farming, which is supposed to represent a holistic approach to production (Anon., 2000). Thus production systems based on grazing and feeding with high levels of roughage must be developed to encourage this production.

Feed intake capacity in Jersey cattle is primarily investigated in dairy cows, based on silage rations and knowledge concerning feed intake capacity in growing cattle on pasture is very limited. Herbage intake and individual digestibility can be estimated by the use of plant wax alkanes (Dove and Mayes, 1991). Additionally, the alkane method offers the possibility to estimate diet composition, giving an accurate estimate on ryegrass/white clover swards (Hameleers and Mayes, 1998).

The objective of this study was to compare herbage intake, feed utilization and diet composition in Danish Holstein and Danish Jersey steers at an age of 8-9 months on a perennial ryegrass/white clover sward.

\section{Materials and methods}

\subsection{Design and samplings}

The experiment was part of a steer production trial using 44 autumn-born Danish Holstein steers and 44 Danish Jersey steers. All steers were reared together the first winter (1999/2000) from an age of 4 to 5 months and were fed a mixed ration of straw and molasses with expected daily gain of 700 and $500 \mathrm{~g} /$ day for Danish Holstein and Danish Jersey, respectively.

From the group of 88 animals, 12 Danish Holstein steers and 13 Danish Jersey steers were randomly selected with respect to age for herbage intake estimation. The steers were turned out on 27 April on perennial ryegrass (Lolium perenne)/white clover (Triifolium repens) pasture, stocking rate 19.1 steers (or $3386 \mathrm{~kg} \mathrm{LW})$ per ha. On 24 May the steers were turned on another pasture, stocking rate 7.1 steers (or $1334 \mathrm{~kg} \mathrm{LW}$ ) per ha. The steers were dosed on 5 June with $\mathrm{C}_{32} / \mathrm{C}_{36}$ alkane boli designed for use in cattle between 100 and $300 \mathrm{~kg}$ LW (Captec Alkane Controlled Release Capsules, Fernz Health and Science, NZ). Their mean LW and age were $251 \pm 14 \mathrm{~kg}$ and $251 \pm 13$ days and $174 \pm 25 \mathrm{~kg}$ and $263 \pm 17$ days for Danish Holstein and Danish Jersey, respectively.
Rectal faecal sampling began 8 days after dosing and samples were taken every second to third day for eight days, i.e. four samples per animal. All samples were taken in the morning. Herbage samples were taken to a height similar to that consumed by the steers $(4 \mathrm{~cm}$ above ground level). The samples were taken at noon once during the 8 days period by a hand-driven lawn mower and with hand shears. A minimum of 50 samplings of $1 \times 1 \mathrm{~m}$ was taken at regular intervals along a predetermined zigzag transect within the paddock. The herbage samples were pooled and sorted in grass stems and leaves, clover stems, leaves and flowers, and freeze-dried. Sward height was maintained at $7 \mathrm{~cm}$ by the addition and removal of non-experimental animals. Sward height was measured with a plate meter $\left(30 \times 30,3.8 \mathrm{~kg} / \mathrm{m}^{2}\right)$ weekly with about 25 measurements per ha.

The animals were weighed monthly during the grazing season, at the time of dosing the bolus and five times during the period of estimating herbage intake. The average LW and daily weight gain for each steers in the period of estimating herbage intake were calculated by a linear regression line based on eight measurements in the period 24 May to 22 June.

\subsection{Estimation of herbage intake and botanical composition}

Pooled herbage samples and plant fractions were freeze-dried to estimate dry matter content in the sward. Herbage samples and samples from the plant fractions (except clover flowers) were analysed for ash, crude protein and digestibility of organic matter (OMD). The digestibility of organic matter in vivo (OMD\%) was determined by NIR analysis. The NIR was calibrated against in vitro digestibility (Tilley and Terry, 1963) and corrected to sheep digestibility at maintenance level by the function $\mathrm{OMD}=4.1+$ $0.959 \times$ in vitro digestibility (Møller et al., 1989). This function is developed by trials with sheep fed with herbage. Pooled herbage samples were additionally analysed for ADF and NDF (Van Soest, 1963).

Faeces was analysed for nematode eggs counts by means of a modified McMaster method (Henriksen and Ågård, 1976) with a sensitivity of 20 eggs per gram of faeces (epg). Faecal samples for alkane analysis were freeze-dried, pooled by animal on an equal weight basis and ground to pass through a $1-\mathrm{mm}$ 
136 sieve. Herbage (1.5 g) and pooled faecal samples (0.5 $137 \mathrm{~g})$ were analysed for $n$-alkanes $\mathrm{C}_{25}-\mathrm{C}_{37}$ by means of 138 gas chromatography following the method of Mayes 139 et al. (1986). An internal standard $\left(\mathrm{C}_{38}\right)$ and alcoholic $140 \mathrm{KOH}$ was added to each sample. The samples were 141 heated overnight and after cooling the alkanes were 142 extracted by heptane and $0.5 \mu 1$ of each purified 143 extract was injected into a gas chromatograph with 144 flame ionization detector (Hewlett Packard GC, HP 145 6890).

146 Herbage intake $(I)(\mathrm{kg} \mathrm{DM})$ was calculated as 147 (Dove and Mayes, 1991) using the synthetic alkane $148 \mathrm{C}_{32}$ and the natural alkanes $\mathrm{C}_{33}: I=\left(F_{i} / F_{j} \times D_{j}\right) /$ $149\left(H_{i}-F_{i} / F_{j} \times H_{j}\right)$.

150 Dry matter digestibility (DMD) was calculated as 151 (Dove and Mayes, 1991) using the alkane $\mathrm{C}_{36}$ : $1521-($ faecal output/intake $)=1-\left(\left(D_{j}+I \times H_{j}\right) / F_{j}\right) / I$.

$153 \quad F_{i}=$ faecal concentration of a natural alkane $(\mathrm{mg} /$ $154 \quad \mathrm{~kg} \mathrm{DM})$

$155 \quad F_{j}=$ faecal concentration of a synthetic alkane $(\mathrm{mg} /$ $156 \quad \mathrm{~kg} \mathrm{DM})$

$157 H_{i}=$ herbage concentration of a natural alkane $(\mathrm{mg} /$ $158 \quad \mathrm{~kg} \mathrm{DM})$

$159 \quad H_{j}=$ herbage concentration of a synthetic alkane $160 \quad(\mathrm{mg} / \mathrm{kg} \mathrm{DM})$

$161 D_{j}=$ daily dosage of synthetic alkane $(\mathrm{mg})$.

t1.1 Table 1

Dry matter content, chemical composition, OMD and alkane content of pooled herbage sample and botanic fractions

$\mathrm{t} 1.3$

Pooled Grass Grass Clover Clover
herbage stems leaves stems leaves sample

\begin{tabular}{lllllll}
\hline Dry matter & 20.6 & 27.7 & 26.4 & 17.1 & 25.4
\end{tabular}

$$
\text { (DM), \% }
$$

$\mathrm{t} 1.5$

t1. 6

$\mathrm{t} 1.7$

$\mathrm{t} 1.8$

t1.9

$\mathrm{t} 1.10$

Ash, \%DM

\begin{tabular}{l}
$9.7-8.8$ \\
\hline
\end{tabular}

11.2

13.9

10.8

Crude protein

20.7
10.7

$16.2 \quad 16.4$

28.0

$\mathrm{ADF}, \% \mathrm{DM}$

20.1

$\mathrm{NDF}, \% \mathrm{DM}$

34.1

In vivo $\mathrm{OMD}$

0.82

$-$

$\begin{array}{ll}- & \\ - & -\end{array}$

Alkane content

(mg/kg DM)

$$
\mathrm{C}_{25}
$$

8.7
21.5
64.5
86.0
63.9
8.8

10.0$$
23.0
$$$$
23.0
$$$$
92.9
$$$$
137.0
$$$$
15.0-24.8-48.3
$$

t1.14 $\mathrm{C}_{31}$

$\mathrm{t} 1.15 \quad \mathrm{C}_{33}$

$\mathrm{t} 1.16$

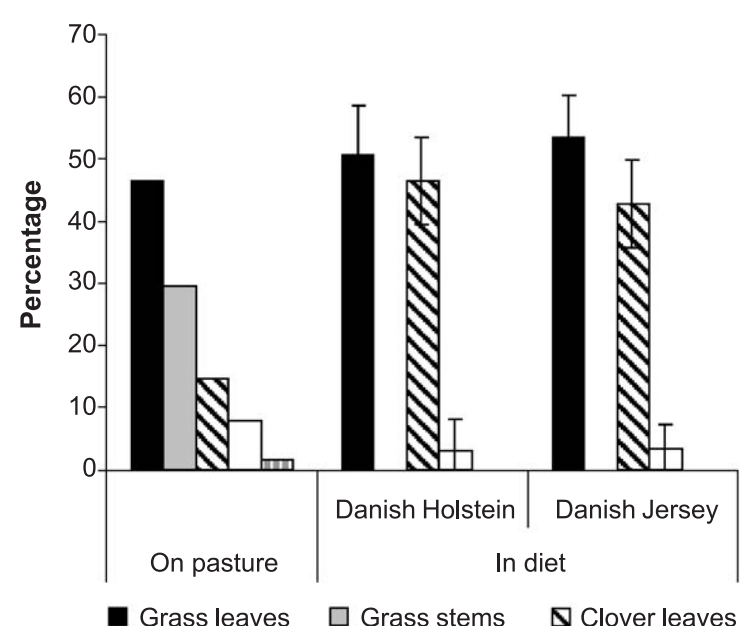

Grass leaves $\square$ Grass stems $\quad \boldsymbol{\Delta}$ Clover leaves

$\square$ Clover stems

$\square$ Clover flowers

Fig. 1. Botanical composition on pasture and in the diet of Danish Holstein and Danish Jersey steers on ryegrass/white clover in June.

The ratio between ryegrass (leaves and stems) and white clover (leaves, stems and flowers) consumed was estimated from the concentrations of the oddchain $n$-alkanes, $\mathrm{C}_{25}-\mathrm{C}_{35}$, in faeces and herbage using a method described by (Dove and Moore, 1995) and called 'non-negative least squares' (NNLS). The method offers the possibility to use more alkanes than plant species in the estimation, and only the non-negative proportion of plant species is used in the results. The program called 'Eatwhat' was used (Dove and Moore, 1995). Alkane content in faeces using for estimation of the botanical composition has to be corrected for recovery of alkanes. The recoveries applied were

Table 2

Liveweight and daily gain on ryegrass/white clover pasture in Danish Holstein and Danish Jersey steers

\begin{tabular}{lcr}
\hline & $\begin{array}{l}\text { Danish Holstein } \\
(n=12)\end{array}$ & $\begin{array}{l}\text { Danish Jersey } \\
(n=13)\end{array}$ \\
\hline $\begin{array}{l}\text { Liveweight, } \mathrm{kg} \\
\text { At turn-out }\end{array}$ & $223 \pm 17$ & $157^{* * *} \pm 29$ \\
$\begin{array}{l}\text { At estimation } \\
\quad \text { of herbage intake }\end{array}$ & $264 \pm 14$ & $185^{* * * \pm 25}$ \\
$\begin{array}{l}\text { At turn-in } \\
\text { Daily gain (kg/day) }\end{array}$ & $381 \pm 23$ & $268^{* * * \pm 30}$ \\
$\begin{array}{l}\text { Before intake estimation } \\
\text { At intake estimation }\end{array}$ & $0.540 \pm 0.243$ & $0.228^{* * \pm 0} \pm 0.282$ \\
Whole period (days 0-187) & $0.848 \pm 0.081$ & $0.594 * * * \pm 0.101$ \\
\hline
\end{tabular}


t3.1 Table 3

Dry matter intake, dry matter digestibility and feed efficiency in Danish Holstein and Danish Jersey steers grazing ryegrass/white

\section{2.3. Statistical analyses}

188 The effect of breed on herbage intake (kg DM, kg $189 \mathrm{DM} / 100 \mathrm{LW}$ and $\mathrm{kg} \mathrm{DM} /$ metabolic LW) on botanical 190 composition of the diet, DMD and feed efficiency was 191 estimated by an analysis of variance. The model with 192 effect on herbage intake was extended with weight

69.4, 78.8, 86.3, 82.1, 84.3 and 82.7 for $\mathrm{C}_{25^{-}}, \mathrm{C}_{27^{-}}$, $\mathrm{C}_{29^{-}}, \mathrm{C}_{31^{-}}, \mathrm{C}_{33^{-}}$and $\mathrm{C}_{35^{-}}$-alkanes, respectively, accordDicker et al., 1996). The proportions estimated by 'Eatwhat' were $\log _{10}$-transformed, as data were not normally distributed. The $\log _{10}$-transformed $(x+1)$ proportions of plant parts in the diet were compared to the botanical composition in pasture to get a selection coefficient (proportion of plant part in the diet/proportion of plant part in pasture). and daily gain as covariates. The botanical composition in the diet between breeds was compared using a paired $t$-test. All statistical analyses were done using SAS (SAS Institute, 1999).

\section{Results}

3.1. Pasture quality, botanical composition and alkane profile ing to values from the literature (e.g. Breinhild, 1999;

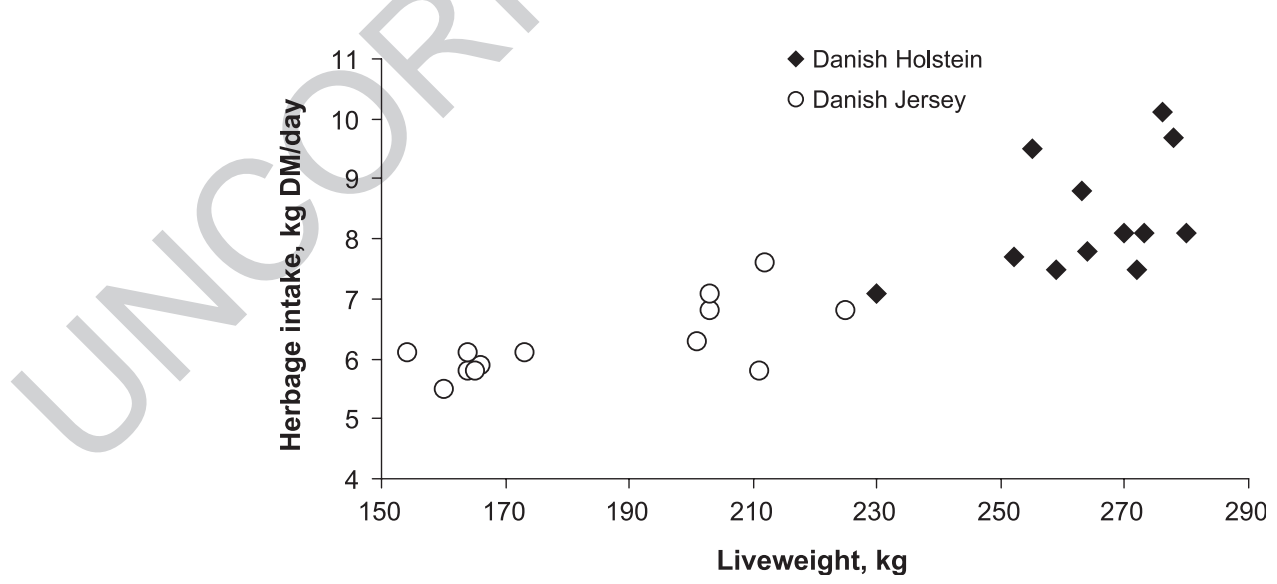

Fig. 2. Herbage intake in relation to liveweight for Danish Holstein and Danish Jersey steers.
The sward height declined from 9.4 (13 June) to 8.0 $\mathrm{cm}$ (20 June) in the period of estimating herbage intake in June. The clover content was $24 \%$ of DM estimated from the herbage sample. The chemical composition of the sward and the different botanical fractions and the alkane profile are presented in Table 1 .

The alkane analysis showed that the botanical composition of the diet was the same for Danish Holstein and Danish Jersey steers with about half of the diet being grass leaves and the other half clover leaves (Fig. 1). The estimate of selectivity was 0.4 for grass leaves, 0 for grass stems, 1.1-1.2 for clover leaves and 0.2 for clover stems.

\subsection{Animal performance and herbage intake}

All steers had a low daily weight gain in the period from turn-out to the time of herbage intake estimation in June (Table 2), possibly due to weight loss in the period immediately following turn-out. Liveweight and daily gain during the grazing period were signif- 
icant different between breeds $(P<0.001)$ and during the period of intake estimation from 24 May to 22 June $(P<0.05)$ (Table 2$)$. No infection with nematodes was found in this period.

Herbage intake per $100 \mathrm{~kg}$ LW was higher for Danish Jersey compared to Danish Holstein $(P<0.05)$ (Table 3). However, when the comparison was made with herbage intake per $\mathrm{kg}$ metabolic LW, there was no difference between the breeds. LW could explain the majority of the observed differences in herbage intake per steer when data was analysed with breed, LW and daily gain included, as there was significant effect of LW $(P<0.001$; $\left.R^{2}=0.78\right)$ and daily gain $(P<0.05)$. No interactions between breed and LW were found (Fig. 2). DMD of the herbage was higher in Danish Jersey compared to Danish Holstein $(P<0.05)$ and no significant difference in feed efficiency between breeds was found (Table 3).

\section{Discussion}

\subsection{Effect of breed and liveweight on herbage intake}

The differences in herbage intake per $100 \mathrm{~kg} \mathrm{LW}$ between the breeds in the present experiment (on average 9\%) were not as big as found in other experiments (on average 19\% and 25\%) (Ingvartsen and Weisberg, 1993; Münger, 1994). These experiments were based on lactating dairy cows having higher energy requirements than steers, possibly giving higher differences between the breeds. Similar to the present results, experiments with steers showed increased dry matter intake per $100 \mathrm{~kg}$ LW in an average of $10 \%$ in Danish Jersey compared to Danish Holsteins when fed with a total mixed ration (Andersen et al., in press). The difference in dry matter intake per $100 \mathrm{~kg} \mathrm{LW}$ between breeds was $16-17 \%$ with a feed ration high in energy (Andersen et al., 1998, in press).

Most experiments in the literature comparing feed intake in Holstein Friesians and Jersey are based on feedstuffs as silage and concentrates, resulting in a lower passage rate compared to grass (Murphy, 1999). The passage rate has effect on feed intake as shown by Ingvartsen and Weisberg (1993). They could explain the higher feed intake per $100 \mathrm{~kg} \mathrm{LW}$ in Jersey cows by a higher passage rate. Similar to the present experiment, lactating Jersey cows on pasture had a $4 \%$ higher dry matter intake per $100 \mathrm{~kg} \mathrm{LW} \mathrm{compared}$ to Holstein Friesians (Mackle et al., 1996).

The analyses showed an effect of LW on herbage intake. It seems that LW can explain the majority of differences in herbage intake between breeds, which also seems obvious from Fig. 2. This explains that no significant differences were found in herbage intake per metabolic LW, whereas differences were found in herbage intake per $100 \mathrm{~kg}$ LW. No interactions between breed and LW were found in the model including both variables. This may be explained due to lack of overlap of LW from the two breeds (Fig. 2).

There was no difference in feed efficiency between breeds in the present experiment. In agreement, efficiency of nutrient utilization in steers, bulls and lactating cows was the same in Jersey and Holstein Friesians fed either ad libitum concentrates or ad libitum high-roughage diets (Blake et al., 1986; Hohenboken et al., 1995; Andersen et al., 1998). However, the difference in efficiency of nutrient utilization for the concentrate and the roughage fed group was smaller for Jersey bulls than for Holstein Friesians (Hohenboken et al., 1995). This could indicate improved energy utilization by Jersey bulls when fed with high-roughage rations compared to Holstein Friesians as found in lactating cows (Oldenbroek, 1988). Jersey cows on pasture had higher feed efficiency when estimated per dry matter intake (Mackle et al., 1996) or estimated per metabolic LW (Münger, 1994) compared to Holstein Friesians (Fig. 3).

In the present experiment, DMD in Jersey steers was higher than in Holsteins. This is somewhat surprising, as the higher dry matter intake could be due to a higher passage rate that will result in a lower DMD. In agreement, no differences in organic matter digestibility (OMD) were observed between Jersey and Holstein Friesians although Jersey had higher feed intake and increased passage rates (Ingvartsen and Weisberg, 1993).

Herbage intake estimated from the alkane method is similar to expected feed intake according to Danish feeding tables $(7.7$ and $6.0 \mathrm{~kg}$ DM for Danish Holstein and Danish Jersey, respectively) (Strudsholm et al., 1999). Thus the feed intake capacity for Danish Jersey was $76 \%$ of the intake capacity of Danish Holsteins 


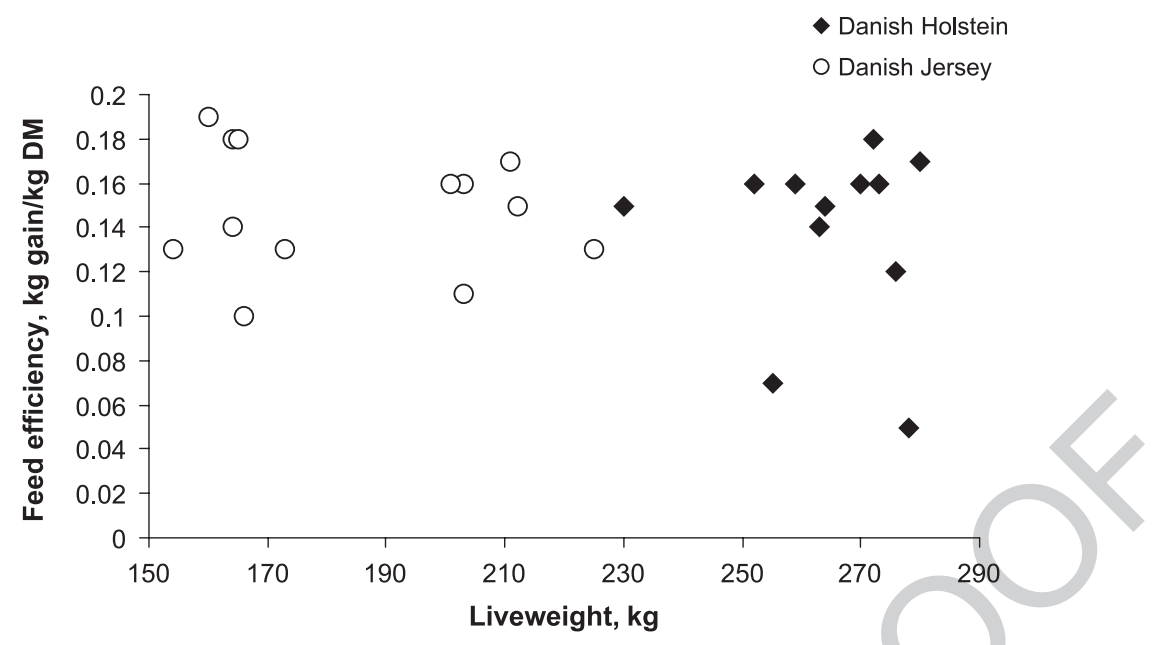

Fig. 3. Feed efficiency in relation to liveweight for Danish Holstein and Danish Jersey steers.

314 that is similar to $79.4 \%$ found by Foldager and Haarbo 315 (1994) in lactating cows fed in the barn.

\subsection{Botanical composition of diet}

The analyses estimated a botanical composition of the diet containing half grass leaves and half clover, whereas grass stems were not found in the diet. Grass stems were found on the pasture ( $30 \%$ of DM), thus it seemed not probably that the steers did not have any intake of grass stems at all, especially if they have a high intake of grass leaves. However, the results suggest that cattle are able to select grass leayes from a mixed pasture. The analyses showed a low goodness of fit, indicating that the alkane patterns of herbage species were not sufficiently different to allow them to be distinguished. This is in agreement with other Danish studies (Nielsen et al., 2003), but contrary to studies with dairy cows fed a ryegrass/white clover mixture in the barn (Hameleers and Mayes, 1998). Additionally, multivariate statistical analysis has shown that especially the alkane patterns of ryegrass and white clover fractions should be distinguished in the analysis (Dove et al., 1996). A condition for an accurate estimation is a representative sample from pasture. In the present experiment, the pasture was very homogenous and it should be expected that the collected sample was representative. When calculating in vivo OMD from plant parts (Table 1) and the botanical composition on pasture as presented in Fig.
1, in vivo OMD in the pooled herbage sample should be 0.82 , which is in agreement with in vivo OMD in the collected pooled herbage sample (Table 1). This result confirms that the collected herbage sample was a representative sample of that which was actually on pasture.

\section{Conclusion}

It is concluded from this grazing experiment that Danish Jersey steers have higher herbage intake per $100 \mathrm{~kg}$ LW than Danish Holstein steers (in average $9 \%)$ of the same age. However, herbage intake per $\mathrm{kg}$ metabolic LW is not different between the two breeds. There is no difference in feed efficiency between the two breeds. The results from this experiment do not indicate that Jersey steers are more efficient in utilizing nutrients from pasture compared to Holstein steers.

\section{References}

Andersen, H.R., Andersen, B.B., Jensen, L.R., Ovesen, E., 1998. Specialproduktion af stærkt marmoreret oksekød. Effekt af race, fodringsstrategi, slagtetidspunkt og opstaldning på produktion, slagte-, kød-og spisekvalitet hos stude. DJF-Report. No.6 Husbandry. Danmarks Jordbrugsforskning, Foulum, Denmark. 55 pp.

Andersen, H.R., Kristensen, T., Bliggaard, H.B., Nielsen, B., 2003. Forskellige produktionssystemer for stude på kløvergræs. DJF- 
Report. Husbandry. Danmarks Jordbrugsforskning, Foulum, Denmark (in press).

Anon., 2000. Basic standards for organic production and processing. Decided by the IFOAM General Assembly in Basel, Switzerland. Ökozentrum Imsbach. Germany.

Blake, R.W., Custodio, A.A., Howard, W.H., 1986. Comparative feed efficiency of Holstein and Jersey cows. J. Dairy Sci. 69 (5), $1302-1308$

Breinhild, C., 1999. Estimering af optagelse, fordøjelighed og sammensætning af græsmarksafgrøder hos græssende svin og kvæg ved anvendelse af $n$-alkananalyse. MSc thesis. The Royal Vet. Agric. University. Copenhagen.

CEC, 1999. Council Regulation on Organic Livestock Production, 1804/1999. Committee of the European Communities, Brussels.

Dicker, R.W., Herd, R.M., Oddy, V.H., 1996. Alkanes and controlled release devices for estimating intake of ryegrass by cattle. Proc. Nutr. Soc. Aust. 20, 107.

Dove, H., Mayes, R.W., 1991. The use of plant wax alkanes as markers substances in studies of the nutrition of herbivores: a review. Aust. J. Agric. Res. 42, 913-952.

Dove, H., Moore, D., 1995. Using a least-square optimization procedure to estimate botanical composition based on the alkanes of plant cuticular wax. Aust. J. Agric. Res. 46, 1535-1544.

Dove, H., Mayes, R.W., Freer, M., 1996. Effects of species, plant part, and plant age on the $n$-alkane concentrations in the cuticular wax of pasture plants. Aust. J. Agric. Res. 47, 1333-1347.

Foldager, J., Haarbo, K., 1994. Effect of breed and feeding intensity during rearing on the feed intake capacity of first lactation dairy cows. Livest. Prod. Sci. 39 (1), 39-42.

Hameleers, A., Mayes, R.W., 1998. The use of $n$-alkanes to estimate herbage intake and diet composition by dairy cows offered a perennial ryegrass/white clover mixture. Grass Forage Sci. 53 (2), $164-169$

Henriksen, S.A., Ågård, K., 1976. A simple flotation and McMaster method. Nordic Vet. Med. 28, 392-397.

Hohenboken, W.D., Foldager, J., Jensen, J., Madsen, P., Andersen, B.B., 1995. Breed and nutritional effects and interactions on energy intake, production and efficiency of nutrient utilization in young bulls, heifers and lactating cows. Acta Agric. Scand., Section A, Anim. Sci. 45 (2), 92-98.
Ingvartsen, K.L., Weisberg, M.R., 1993. Jersey cows have a higher feed intake capacity and higher rate of passage then Friesians cows. Arch. Tierz., Dummerstorf 5, 495-498.

Mackle, T.R., Parr, C.R., Stakelum, G.K., Bryant, A.M., MacMillan, K.L., 1996. Feed conversion efficiency, daily pasture intake, and milk production of primiparous Friesian and Jersey cows calved at two different liveweights. N.Z. J. Agric. Res. 39 (3), $357-370$.

Mayes, R.W., Lamb, C.S., Colgrove, P.M., 1986. The use of dosed and herbage $n$-alkanes as markers for the determination of herbage intake. J. Agric. Sci., Cambridge 107, 161-170.

Møller, E., Andersen, P.E., Witt, N., 1989. En sammenligning af in vitro opløselighed og in vivo fordøjelighed af organisk stof i grovfoder. Beretning fra Fællesudvalget for Statens Planteavlsog Husdyrbrugsforsøg, vol. 13. Foulum, Denmark. 23 pp.

Münger, A., 1994. Efficiency of different cow breeds. Agrarforschung 1 (9), 389-392.

Nielsen, B., Thamsborg, S.M., 2002. Dairy bull calves as a resource for organic beef production: a farm survey in Denmark. Livest. Prod. Sci. 75 (3), 245-255.

Nielsen, B., Thamsborg, S.M., Andersen, H.R., Kristensen, T., 2003. Effect of winter feeding level and season on herbage intake in dairy breed steers on perennial ryegrass/white clover pasture. Anim. Sci. 76, 341-352.

Murphy, M., 1999. Rumen metabolism and nutrient supply in lactating cows on pasture. Grazing Pasture and Management in the Nordic Countries. Proceedings from NJF-Seminar No. 305, Ås, Norway, 27. June 1999, pp. 38-44.

Oldenbroek, J.K., 1988. The performance of Jersey cows and cows of larger dairy breeds on two complete diets with different roughage contents. Livest. Prod. Sci. 18 (1), 1-17.

SAS Institute, 1999. Version 8. Cary, NC, USA.

Strudsholm, F., Aas, O., Madsen, J., Kristensen, V.F, Andersen, R.H., Hvelplund, T., Østergaard, S., 1999. Danske fodernormer til kvæg. Report no. 84. The Danish Agricultural Advisory Center, Skejby. 51 pp.

Tilley, J.M., Terry, R.A., 1963. A two-stage technique for the in vitro digestion for forage crops. J. Br. Grassl. Soc. 18, 104-110.

Van Soest, P.J., 1963. Use of detergents in the analyses of fibrous feeds. A rapid method for the determination of fiber and lignin. J. Assoc. Off. Agric. Chem. 46, 829-835. 